\title{
A Meta-Analysis on Locus of Control and Ethical Compliance among Professional Auditors in Nigeria
}

\author{
Stanley Ogoun, Odogu Terry Keme Zuode \\ Department of Accountancy, Management Sciences, Niger Delta University, Wilberforce Island, Bayelsa State, Nigeria \\ Email: stanleyogoun@ndu.edu.ng,odoguterry@gmail.com
}

How to cite this paper: Ogoun, S., \& Zuode, O. T. K. (2020). A Meta-Analysis on Locus of Control and Ethical Compliance among Professional Auditors in Nigeria. Open Journal of Accounting, 9, 1-14.

https://doi.org/10.4236/ojacct.2020.91001

Received: January 1, 2020

Accepted: January 28, 2020

Published: January 31, 2020

Copyright (อ 2020 by author(s) and Scientific Research Publishing Inc. This work is licensed under the Creative Commons Attribution International License (CC BY 4.0).

http://creativecommons.org/licenses/by/4.0/

\section{(c) (i) Open Access}

\begin{abstract}
This study meta-analytically pooled and synthesized thirty studies related to ethical compliance and locus of control in the light of auditors' independence and public and professional commitment. This was informed by the increasing corporate and audit failures recorded in the early 2000s despite existing professional ethics. Qualitative information were obtained from synthesized related studies and coded into quantitative data for analysis. The translated data were tested using OLS with the E-view 9 software for correlation and regression analyses. The regression analysis revealed a strong positive relationship between locus of control and ethical compliance, hence, the only hypothesis in the study was rejected, and the conclusion of the study is that, "ethical compliance is a function of an individual accountant or auditor's locus of control". Consequently, the study recommends that professional bodies and institutions should consider personality factors in the setting and implementation of professional ethics.
\end{abstract}

\section{Keywords}

Meta-Analysis, Auditors Independence, Ethical Compliance, Locus of Control

\section{Introduction}

The corporate world is inundated with several instances of corporate scandals, with cascading multiplier effect. The enormity of these phenomena has continued to attract concerted efforts from multiple stake holders. This much is evidenced in its landmark presence globally. Interestingly, the bigger economies have witnessed more of this narrative in their private sector domain than even 
the smaller economies resulting in various corporate reform programmes being initiated at addressing this ugly phenomenon. However, it continues to defy and undermine the espoused measures.

As recognized in the extant literature, at the hearth of this problem is the human factor. This is evidenced in the tail of culpabilities associated with the various reported and celebrated cases of the corporate giants that were mauled down by this overwhelming human creation. A look at the documented literature on corporate scandals details various corporate giants that became casualties of its devastating effect. For instance, the global financial meltdown that rocked the world in 2008 was a fall out of its manifestation. Also, the Too Big to Fail (TBTF) policy initiated in the United States of America was a fallout of public measures aimed at containing the catastrophic multiplier effects of giant corporate failures. This is indicative of the global nature of this problem.

Against the foregoing background, international or global, national governments, regulatory agencies and investors, etc. have continued to search for the antidote or insulin required to tame this monster. The reforms by way of regulatory controls, reporting requirements, corporate governance measures, etc. geared towards quarantining of this virus have not yielded the required result. What this scenario indicates, is the obvious fact that it is a human problem, as history has taught us over time the fact that human cravings can undermine even the best of laws and compromise the most efficient system. If this were not the case, there would have been no need for prisons and correctional facilities. Also, crime as clearly prohibited by various laws would have been eliminated from the human race. We appear to be in a circus. History keeps repeating itself, as if we are so configured to err.

However, premised on the fraud triangle theory, it is indicative that fraudulent conduct as a human problem is more of a function of individual rational domain and subsequent behavioural dispositioned. The behavioural disposition is the physical objectification of the rationalized mind set. Thus, an individual's behavioural disposition is always grounded in the individual's mind set. Psychologists have observed that even under peer group influence, the individual cognitive frame plays a significant role. This probably accounts for the fact that not all persons working in the corporate world or other settings are involved in unethical conducts. If it were so, no human entity that is not commonly owned would have survived. The concept of separation of ownership of business from control as espoused in the accounting template would have been irrelevant.

Furthermore, as recognized by every world of human professional conduct, ethics is considered as a major defining plank of each profession. A cursory look at the various codes of ethics governing the various professional practices clearly throws out the human problem. Thus, ethics is a human problem (O'Bryan \& Donnelly, 2011; Asni, Dali, Dharmawaty, \& Syafitri, 2018; Sahla \& Iryanie, 2018). While, compliance is demanded with the threat of reprimand, self-regulation is often the preferred model. This much is emphasized by the numerous professional ethics compliance demand templates. It is in this regard that the current 
study did examine locus of control and ethical compliance amongst professional auditors.

\section{Literature Review and Hypothesis Development}

\subsection{Auditor's Independence}

Uyar \& Güngörmüş (2013) found in their study that, "auditing is the most and only course in which ethics should be taught". This perhaps is due to the importance of objectivity and independence which the public and professional ethics are daily advocating for (Bakar, Rahman, \& Rashid, 2005). Generally, auditors' independence is the joint probability that, in compliance with professional ethics and competence, auditors will find and report misstatements in financial statements presented before them (DeAngelo, 1981). Auditors' independence has come under increased scrutiny over the past several years due to highly publicised accounting scandals and audit failures. This is evident in the cases of Arthur Andersen, Enron, Adelphia Communications, Dynegy, WorldCom and Tyco, and therefore necessitates a continuous revision, renewal and enforcement of codes of professional ethics in the accounting and auditing profession (Esmond-Kiger, 2004; Dellaportas, 2006; Steinhoff \& Hoffman, 2015).

\subsection{Professional Ethics and Compliance}

Generally, ethics can be described as a code of conduct that applies to everyday life (Alnasser, Shaban, \& Al-Zubi, 2014). Ethics in the accounting parlance is a body of predetermined codes which guide the conduct of accountants towards reliability, accuracy and objectivity in discharging their duties (Enofe, Nakpodia, \& Moruku, 2014). It is a desired and expected moral and legal type of behaviour from an accounting professional (Nwakpa, 2010). These codes are developed, written and issued by the International Ethics Standards Board for Accountants (IESBA).

Ethical considerations and compliance is drawing attention by the day ( $\mathrm{Na}-$ than, 2015; Cameron \& O'Leary, 2015). This is due to the complex nature of data processing and reporting in the $21^{\text {st }}$ century, which has made financial reporting and auditing susceptible to professional manipulations (Jones \& Abraham, 2007). This, of course, is evident by the recent corporate scandals of Enron, Tyco, Dynergy, Adelphia Communications, and WorldCom that have tarnished the reputation of the profession (Koumbiadis \& Okpara, 2008; Enofe, Nakpodia, \& Moruku, 2014). Consequently, ethics has become the core of accounting or auditing (Javeed, n.d.). Thus, Ibidunni, Okere, Ibidunni, Joshua \& Okah (2018) saw a significant association between accounting ethics and performance of audit firms in Nigeria. However, Enofe, Nakpodia, \& Moruku (2014) also noted that, "ethics in the conduct of professional accountants has its own challenges". Hence, the need to investigate the factors associated with the practicability of professional ethics.

Alnasser, Shaban, \& Al-Zubi (2014) argued that, "ethical decision-making arises 
from two levels of moral reasoning, namely intuitive and critical evaluative levels". According to them, the intuitive level entails individual's personal feelings and ideas about what is right and wrong in a given, and is a function of the individual's personal beliefs, knowledge and experiences. Similarly, Belverd, Powers, Sherry, \& Henry (1999) noted that ethical behaviour in organisations is a function of the actions and decisions of the employees. On the other hand, Alnasser, Shaban, \& Al-Zubi (2014) adduced that the critical evaluative level entails reasoned judgments and evaluations, which is the application of moral reasoning to situations. This seems to suggest a relationship between ethics and locus of control.

\subsection{Locus of Control}

Locus of control is an important factor in the explanation of human behaviour in organisations (Spector, 1982). It emanated from the Social Learning Theory propounded by Rotter in 1954. Locus of control is the extent to which individuals believe that they can control events which affect them (Hurrell Jr., Levi, \& Murphy, 2011). It is a personality trait that reflects the generalised belief that events in life are either controlled by one's own action or by external influences (Fagbola \& Popoola, 2015). Locus of control can be internal or external (Fagbola \& Popoola, 2015). Internal locus of control refers to the control of events by one's own action. Individuals with internal locus of control are ingenious, careful, alert, dominant, focused and self-confident. Such individuals are optimistic and believe that they can positively exert control over life events, circumstances and the associated reinforcements.

On the other hand, external locus of control is the control of events by forces outside an individual. Individuals with external locus of control are less careful, less self-confident, easily influenced by group members and display unsteady performances. Such individuals believe they have little control over life events and circumstances, and therefore attribute reinforcements to chance, luck or other powerful individuals (Selart, 2005; Ozen-Kutanis, Mesci \& Ovdur, 2011; Hurrell Jr. et al., 2011).

However, internal locus of control has a much bigger impact on individuals than external locus of control (Igbeneghua \& Popoola, 2011). Against this background, Neaves (1989) opined that internal locus of control and individual decision-making are significantly and statistically related. The projections above seem to associate behavioural actions which professional ethics seek to guide with locus of control. On this premise, the null hypothesis of this study is:

$\mathrm{H}_{\mathrm{o}}$ : Ethical compliance is not a function of an individual s locus of control.

\subsection{Related Empirical Studies}

A meta-analysis of articles on professional ethics and locus of control in the light of independent, objective, reliable and effective judgement and decision-making, which is the core of auditing, and of course, the expectation of the public is necessary. 


\section{Methodology}

This is a mixed study designed to obtain and convert desirable qualitative information into quantitative data. Qualitative data would be obtained by meta-analytically synthesizing the findings and or conclusions of 30 related studies on the relationship between locus of control and professional ethical compliance. Information to be pooled and synthesized would cover a period of 30 years (1996 to 2019) and would be converted to quantitative data through coding. The two variables of the study are ethical compliance which is the dependent variable and locus of control being the independent variable. This is illustratively specified in the model below:

$$
E T C=\beta_{o}+\beta L O C+U t
$$

where:

$E T C=$ Ethical compliance is the dependent variable. This is surrogated by words like professional competence, auditor behaviour, organisational commitment, whistle blowing, etc.

$L O C=$ Locus of Control is the independent (explanatory) variable. This is surrogated by words like, personality variable, emotional spiritual quotient, etc.

The occurrence of the dependent variable (ethical compliance) would be coded and statistically presented based on the research hypothesis, over the period under study. The independent variable (locus of control) on the other hand would be coded based on the number of related studies captured and synthesized in each of the years within the period of study. Specifically, data would be generated from table 2.1 and coded and presented for correlation and regression tests and analyses, using "Ordinary Least Square (OLS)" statistical tool and technique with E-view 9 computer software, in the next section of this study. This would inform the acceptance or rejection of the hypothesis of the study.

\section{Data Presentation, Analysis and Findings}

\subsection{Data Presentation and Analysis}

Table 1 is generated from the summarised findings and conclusions of 30 related articles studies in Table 2. The synthesized (qualitative) information in Table 2 are coded into quantitative data. This is achieved by introducing an alternate hypothesis $\left(\mathrm{H}_{\mathrm{A}}\right)$ for assertions contrary to the null hypotheses $\left(\mathrm{H}_{\mathrm{o}}\right)$. Every finding, assertion, observation and proposition germane to the objective of this study is given a score of 1 and is recorded in favour of $\mathrm{H}_{\mathrm{o}}$ or $\mathrm{H}_{\mathrm{A}}$ in each of the years under study. However, where no assertion is made in any year or in respect of any hypothesis, 0 is recorded against such year or hypothesis. The data do not reflect publication bias, because the assertions captured are both in the positive and negative, which implies that the selected studies report both favourable and unfavourable estimates. For instance, Hastuti, Setianingrum, \& Sundari (2015) and Zarefar \& Zarefar (2017) did not report any relationship between locus of control and ethical compliance. 
Table 1. Meta-analysis result on ethics and locus of control.

\begin{tabular}{|c|c|c|c|}
\hline \multirow{3}{*}{ Years } & \multicolumn{2}{|c|}{ Dependent Variable } & \multirow{3}{*}{$\begin{array}{c}\begin{array}{c}\text { Independent } \\
\text { Variable }\end{array} \\
\text { LOC }\end{array}$} \\
\hline & \multicolumn{2}{|c|}{ ETC } & \\
\hline & Null Hypothesis & Alternate Hypothesis & \\
\hline 1996 & 0 & 1 & 0 \\
\hline 1997 & 0 & 0 & 0 \\
\hline 1998 & 0 & 0 & 0 \\
\hline 1999 & 0 & 1 & 1 \\
\hline 2000 & 0 & 0 & 0 \\
\hline 2001 & 0 & 0 & 0 \\
\hline 2002 & 0 & 0 & 0 \\
\hline 2003 & 0 & 2 & 2 \\
\hline 2004 & 0 & 0 & 0 \\
\hline 2005 & 0 & 1 & 1 \\
\hline 2006 & 0 & 0 & 0 \\
\hline 2007 & 0 & 1 & 1 \\
\hline 2008 & 0 & 1 & 1 \\
\hline 2009 & 0 & 0 & 0 \\
\hline 2010 & 0 & 1 & 1 \\
\hline 2011 & 0 & 5 & 5 \\
\hline 2012 & 0 & 0 & 0 \\
\hline 2013 & 0 & 2 & 2 \\
\hline 2014 & 0 & 1 & 1 \\
\hline 2015 & 1 & 1 & 2 \\
\hline 2016 & 0 & 0 & 0 \\
\hline 2017 & 1 & 4 & 5 \\
\hline 2018 & 0 & 4 & 4 \\
\hline 2019 & 0 & 3 & 3 \\
\hline Total & 2 & 28 & 30 \\
\hline
\end{tabular}

Source: Author's computation from synthesized studies in Table 2.

From the descriptive statistics in Table 3, the Jarque-Bera Chi Squares of ETC (9.84) and LOC (9.62) are both higher than the descriptive probability values (0.01 and 0.01). This implies that the result portrays a goodness of fit.

\subsection{Hypothesis Testing and Findings}

The correlation analysis result in Table 4 above shows that the dependent variable, ETC is strongly and positively related to the independent variable, LOC. Specifically, the correlation between ETC and LOC is approximately $99 \%$. This implies a strong positive relationship. 
Table 2. A meta-analysis of studies on professional ethics and locus of control.

\begin{tabular}{|c|c|c|c|c|}
\hline $\mathbf{S} / \mathbf{N}$ & Year & Author(s) & Research Topic & Synthesized Findings and Conclusions \\
\hline 1 & 1996 & Tsui & $\begin{array}{l}\text { Auditors' ethical reasoning: Some audit conflict } \\
\text { and cross cultural evidence. }\end{array}$ & $\begin{array}{l}\text { Ethical reasoning moderates the relationship } \\
\text { between locus of control and auditor's } \\
\text { capability to reject management pressure. }\end{array}$ \\
\hline 2 & 1999 & Rutledge \& Karim & $\begin{array}{l}\text { The influence of self-interest and ethical } \\
\text { considerations on manager's evaluation } \\
\text { judgements. }\end{array}$ & $\begin{array}{l}\text { There is a significant relationship between locus } \\
\text { of control and ethical considerations in } \\
\text { manager's policy evaluation. }\end{array}$ \\
\hline 3 & 2003 & Kwan-Chiu & $\begin{array}{l}\text { Ethical Judgment and Whistleblowing } \\
\text { Intention: Examining the Moderating Role of } \\
\text { Locus of Control. }\end{array}$ & $\begin{array}{l}\text { Individuals' locus of control moderates the } \\
\text { relationship between ethical judgment and } \\
\text { whistleblowing. }\end{array}$ \\
\hline 4 & 2003 & Susaniti & $\begin{array}{l}\text { The influence of ethical considerations and } \\
\text { locus of control on managers' evaluation } \\
\text { judgements at the adverse selection codition. }\end{array}$ & $\begin{array}{l}\text { Locus of control moderates the relationship } \\
\text { between ethics and manager's policies in } \\
\text { decision making. }\end{array}$ \\
\hline 5 & 2005 & Forte & $\begin{array}{l}\text { Locus of control and the moral reasoning of } \\
\text { managers }\end{array}$ & $\begin{array}{l}\text { Individuals' internal locus of control impact } \\
\text { their ethical behaviour in organisations. }\end{array}$ \\
\hline 6 & 2007 & $\begin{array}{l}\text { Smith, Hume, \& } \\
\text { Zimmermann }\end{array}$ & $\begin{array}{l}\text { The global significance of locus of control in } \\
\text { ethical decision making: A multi-country } \\
\text { examination of university students. }\end{array}$ & $\begin{array}{l}\text { Locus of control is a personality variable that } \\
\text { possesses potential explanatory power in ethical } \\
\text { decision making. }\end{array}$ \\
\hline 7 & 2008 & Ojedokun & $\begin{array}{l}\text { Attitude towards unethical work behaviour } \\
\text { among police personnel: The role of emotions }\end{array}$ & $\begin{array}{l}\text { There is a significant influence of emotional } \\
\text { intelligence and self-regulation on attitude } \\
\text { towards unethical work behaviour. }\end{array}$ \\
\hline 8 & 2010 & Ornoy & $\begin{array}{l}\text { Correlates of employees' attitudes towards } \\
\text { participation in decision making. }\end{array}$ & $\begin{array}{l}\text { Internal locus of control is positively related to } \\
\text { individual's attitude at work place. }\end{array}$ \\
\hline 9 & 2011 & $\begin{array}{l}\text { Ozen-Kutanis, } \\
\text { Mesci, \& Övdür }\end{array}$ & $\begin{array}{l}\text { The effects of locus of control on learning } \\
\text { performance: A case of an academic } \\
\text { organization }\end{array}$ & $\begin{array}{l}\text { Individuals with internal locus of control have } \\
\text { more active work motivation and portray } \\
\text { effective work performance. }\end{array}$ \\
\hline 10 & 2011 & Hung \& Hsu & $\begin{array}{l}\text { Impact of locus of control, changes in work load } \\
\text { and career prospects on organisational } \\
\text { commitment of employees of life insurance } \\
\text { companies during merger and acquisition. }\end{array}$ & $\begin{array}{l}\text { Locus of control has significant effect on } \\
\text { organisational (as well as professional or } \\
\text { ethical) commitment. }\end{array}$ \\
\hline 11 & 2011 & Boshoff \& Zyl & $\begin{array}{l}\text { The relationship between locus of control and } \\
\text { ethical behaviour among employees in the } \\
\text { financial sector }\end{array}$ & $\begin{array}{l}\text { Locus of control, an individual factor influences } \\
\text { ethical behaviour. }\end{array}$ \\
\hline 12 & 2011 & $\begin{array}{l}\text { Igbeneghua \& } \\
\text { Popoola }\end{array}$ & $\begin{array}{l}\text { Influence of locus of control and job satisfaction } \\
\text { on organizational commitment: A study of } \\
\text { medical records personnel in University } \\
\text { Teaching Hospitals in Nigeria. }\end{array}$ & $\begin{array}{l}\text { Individuals that have internal locus of control } \\
\text { are likely to be more committed to their } \\
\text { organisations. }\end{array}$ \\
\hline 13 & 2011 & O’Bryan \& Donnelly & $\begin{array}{l}\text { Locus of control and dysfunctional audit } \\
\text { behaviour. }\end{array}$ & $\begin{array}{l}\text { Dysfunctional audit behaviour is statistically } \\
\text { related to a personality variable called locus of } \\
\text { control. }\end{array}$ \\
\hline 14 & 2013 & $\begin{array}{l}\text { Ozbek, Alniacik, } \\
\text { Akkilic, \& Koc }\end{array}$ & $\begin{array}{l}\text { The moderating role of locus of control on the } \\
\text { links between perceived ethical problem and } \\
\text { ethical intentions of marketing managers in } \\
\text { Turkey. }\end{array}$ & $\begin{array}{l}\text { Locus of control moderates the relationships } \\
\text { between perceived ethical problem and ethical } \\
\text { intentions. }\end{array}$ \\
\hline
\end{tabular}




\section{Continued}

15

2010 Thompson

16

2014 Alnasser, Shaban, \&
Al-Zubi

Hastuti,

2015 Setianingrum, \&

Sundari

2015 Fagbola \& Popoola

Zarefar \& Zarefar

Sulistiyo \& Ghozali

Aulia, Laksamana, \&

Basuki

Dali, Sari, \&

Chaerani

Abiola, Lawal, \& Odunjo-saka

Asni, Dali,

Kartasari, Tjaraka, \& Sudaryati
The impact of locus of control on decision making styles of midlevel managers

The impact of accounting ethics in improving managers' behavior and decision making in the Jordanian companies

The influence of the complexity of the task, locus of control and gender on the performance of auditors in Surubaya Indonesia.

Influence of locus of control, work motivation and information use on decision-making of managers in the Aviation industry in Nigeria.

Emotional intelligence as a moderator between perceived organisational injustice and organisational deviance among public sector employees

The influence of ethics and locus of control to do whistle blowing intention with profession of auditor and non-auditor as a moderating variable.

The role of religious control in dysfunctional audit behaviour

Locus of control and the acceptance of dysfunctional audit behaviour in a review of philosophy semar.

The influence of locus of control and organisation ethical decision of auditors (study on BPKP representative of Southeast Sulawesi Province).

Role of locus of control and perceived effort-reward imbalance in attitude toward unethical work behaviour.

The influence of locus of control and professional commitment toward auditor's behaviour in conflict situation.

The effect of professionalism, ESQ and locus of control on acceptance dysfunctional behaviour with performance of internal auditor as an intervening variable.

Perception of locus of control, level of education, Machiavellianism and ethical reasoning against auditor behaviour in audit conflict situations.
Locus of control has a positive influence in the decision making process of managers.

Ethical actions are the product of individual decisions.

Locus of control does not affect the performance of auditors.

Individual's locus of control has a positive and significant influence on managerial decision.

Emotional intelligence significantly moderates the relationship between the three dimensions of perceived organisational injustice and deviance.

There is a negative relationship between locus of control and whistle blowing in auditing.

Locus of control has a positive relationship with organisational (ethical) commitment.

An auditor with a high level of internal locus of control is more efficient and ethical in the discharge of his audit assignment.

Locus of control and organisational culture simultaneously have a positive and significant impact on auditor decision making.

Unethical work behaviour among members of FRSC in Nigeria is a function of how they believe they are not in control and responsible of and for their actions.

Locus of control has a positive (significant) influence on auditors' decision and behaviour in conflict situations.

Professionalism, Emotional Spiritual Quotient (ESQ) and locus of control are directly related to dysfunctional behaviour.

Individual factors such as locus of control and ethical reasoning significantly affect auditor behaviour in conflict situations. 


\section{Continued}

$282019 \begin{aligned} & \text { Hanjani, Purwanto, } \\ & \text { \& Kusuma-dewi }\end{aligned}$

$292019 \quad$ Sulistiyo

30

2019 Alam \& Alam
The impact of ethical judgment, locus of control, and organizational commitments to whistleblowing.

Locus of control, dysfunctional audit behaviour and the mediating role of organisational commitment.

The effect of personal ethical philosophy, internal locus of control and academic culture on professional competence of accountant educators in private universities in Makassar.
Ethical judgement, locus of control and organizational commitments have positive and significant influence to auditor intention in doing whistleblowing.

Locus of control decreases dysfunctional audit behaviour.

Internal locus of control significantly affects professional competence of accountants.

Source: Author's Compilation \& Summary from Studies between 1990 \& 2019.

Table 3. Descriptive statistics.

\begin{tabular}{|c|c|c|}
\hline Parameters & ETC & LOC \\
\hline Mean & 1.076923 & 1.153846 \\
\hline Maximum & 5.000000 & 5.000000 \\
\hline Std. Dev. & 1.440085 & 1.541228 \\
\hline Skewness & 1.420836 & 1.409471 \\
\hline Kurtosis & 4.005891 & 3.964348 \\
\hline Jarque-Bera & 9.844162 & 9.616100 \\
\hline Probability & 0.007284 & 0.008164 \\
\hline Sum & 28.00000 & 30.00000 \\
\hline Sum Sq. Dev. & 51.84615 & 59.38462 \\
\hline Observations & 26 & 26 \\
\hline
\end{tabular}

Source: Author's computation from E-view 9.

Table 4. Correlation test.

\begin{tabular}{cccc}
\hline & ETC & LOC \\
\hline ETC & 1 & 0.98566 \\
LOC & 0.98566 & 1 & 1
\end{tabular}

Source: Author's computation from E-view 9.

From Table 5, the Adjusted R-Squaredis 0.97 (97\%). This implies that the dependent variable (ETC) is positively and strongly related to the independent variable (LOC). Furthermore, the Durbin-Watson statistic (2.53) is greater than 1.90. This again represents a strong (significant) positive correlation between the dependent and independent variables. Moreover, the probability outcome (0.00) 
Table 5. OLS regression analysis.

\begin{tabular}{|c|c|c|c|c|}
\hline \multicolumn{5}{|l|}{ Method: Least Squares } \\
\hline \multicolumn{5}{|c|}{ Date: 08/01/19 Time: $21: 10$} \\
\hline \multicolumn{5}{|c|}{ Sample (adjusted): 19982019} \\
\hline \multicolumn{5}{|c|}{ Included observations: 22 after adjustments } \\
\hline Variable & Coefficient & Std. Error & t-Statistic & Prob. \\
\hline $\mathrm{C}$ & 0.000450 & 0.070755 & 0.006364 & 0.9950 \\
\hline LOC & 0.930044 & 0.034600 & 26.87974 & 0.0000 \\
\hline $\operatorname{ECM}(-1)$ & 0.073595 & 0.037315 & 1.972263 & 0.0633 \\
\hline R-squared & 0.974498 & \multicolumn{2}{|c|}{ Mean dependent var } & 1.227273 \\
\hline Adjusted R-squared & 0.971813 & \multicolumn{2}{|c|}{ S.D. dependent var } & 1.509709 \\
\hline S.E. of regression & 0.253464 & \multicolumn{2}{|c|}{ Akaike info criterion } & 0.218938 \\
\hline Sum squared resid & 1.220641 & \multicolumn{2}{|c|}{ Schwarz criterion } & 0.367716 \\
\hline Log likelihood & 0.591685 & \multicolumn{2}{|c|}{ Hannan-Quinn criter. } & 0.253986 \\
\hline F-statistic & 363.0130 & \multicolumn{2}{|c|}{ Durbin-Watson stat } & 2.529280 \\
\hline Prob (F-statistic) & 0.000000 & & & \\
\hline
\end{tabular}

Source: Author's computation from E-view 9.

is less than $5 \%$ or 0.05 which implies that the dependent variable (ETC) is statistically significant. Using the bench-mark of 2.0 and above against the t-Statistic regression outcomes, the regression result is greater than 2.0. This shows that the dependent variable in the research model is statistically significant, and therefore implies that the Null Hypothesis is to be rejected in favour of the Alternate. This is because the rule for acceptance and rejection of hypothesis using the $\mathrm{t}$-Statistic says that, "if t-Calculated (Statistic) in the regression model is higher than $\mathrm{t}$-Tabulated in the $\mathrm{t}$-test table, the Null Hypothesis $\left(\mathrm{H}_{0}\right)$ is rejected for the Alternate $\left(\mathrm{H}_{\mathrm{A}}\right)$ and vice versa". Consequently, the regression analysis reveals that, "ethical compliance is a function of an individual's locus of control".

\section{Conclusion, Limitation and Recommendations}

This study seeks to examine the relationship between locus of control and professional ethical compliance. It is motivated by the numerous instances of corporate scandals and their debilitating effect. Premised on the fraud triangle, the rationale domain and behavioural disposition of practicing auditors (in the light of professional independence) was qualitatively sought by meta-analysing and synthesizing the assertions, findings and conclusions of thirty related studies from 1996 to 2019. The meta-analysed qualitative information were translated to quantitative measurable data through coding and were tested with E-View 9 for correlation. 
The test results reveal a strong statistically significant association between locus of control and ethical compliance. Specifically, the regression analysis result shows that locus of control significantly influences accountants particularly auditors in the performance of their duties. This is in tangent with over ninety percent of the meta-synthesized studies in Table 2. Consequently, this study concludes that, ethics is not an end in itself, but a means to an end. Certainly, ethical compliance is more of a personal decision than a collective goal. Above all, ethical compliance is a function of an individual accountant or auditor's locus of control. It is therefore recommended that professional bodies and institutions should note the significance of individual differences and locus of control in the establishment and enforcement of professional ethics.

\section{Conflicts of Interest}

The authors declare no conflicts of interest regarding the publication of this paper.

\section{References}

Abiola, S. S., Lawal, A. M., \& Odunjo-saka, K. A. (2018). Role of Locus of Control and Perceived Effort-Reward Imbalance in Attitude toward Unethical Work Behaviour. IFE PsychologIA, 26, 222-233.

Alam, S., \& Alam, R. (2019). The Effect of Personal Ethical Philosophy, Internal Locus of Control and Academic Culture on Professional Competence of Accountant Educators in Private Universities in Makassar. Journal of Academic Research and Sciences, 4, 13-27. https://doi.org/10.35457/jares.v4i1.692

Alnasser, N., Shaban, O. S., \& Al-Zubi, Z. (2014). The Impact of Accounting Ethics in Improving Managers' Behavior and Decision Making in the Jordanian Companies. British Journal of Economics, Management \& Trade, 4, 1441-1456. https://doi.org/10.9734/BJEMT/2014/9682

Asni, N. Dali, N., Dharmawaty, T., \& Syafitri, A. A. (2018). The Influence of Locus of Control and Professional Commitment toward Auditor's Behaviour in Conflict Situation. Journal of Economics and Finance, 9, 75-83.

Aulia, Y., Laksamana, A., \& Basuki (2017). Locus of Control and the Acceptance of Dysfunctional Audit Behaviour in a Review of Philosophy Seminar. International Journal of Scientific and Research Publications, 7, 264-269.

Bakar, N. B. A., Rahman, A. R. A., \& Rashid, H. M. A. (2005). Factors Affecting Auditor Independence: Malaysian Loan Officers, Perceptions. Managerial Auditing Journal, 20, 804-822. https://doi.org/10.1108/02686900510619665

Balogun, A. (2017). Emotional Intelligence as a Moderator between Perceived Organisational Injustice and Organisational Deviance among Public Sector Employees. International Journal of Management Practice, 10, 175-188.

https://doi.org/10.1504/IJMP.2017.083084

Belverd E. N., Powers, M., Sherry, K. M., \& Henry, A. R. (1999). Principles of Accounting (7th ed.). Boston, MA: Houghton Mifflin.

Boshoff, E., \& Zyl, E. V. (2011). The Relationship between Locus of Control and Ethical Behaviour among Employees in the Financial Sector. KOERS, 76, 283-303.

https://doi.org/10.4102/koers.v76i2.17 
Cameron, A. R., \& O'Leary, C. (2015). Improving Ethical Attitudes or Simply Teaching Ethical Codes? The Reality of Accounting Ethics Education. Accounting Education, 24, 275-290. https://doi.org/10.1080/09639284.2015.1036893

Dali, N., Sari, I. M., \& Chaerani, D. R. (2017). The Influence of Locus of Control and Organisation Ethical Decision of Auditors (Study on BPKP Representative of Southeast Sulawesi Province). Journal of Business and Management, 19, 23-28.

DeAngelo, L. (1981). Auditor Size and Audit Quality. Journal of Accounting and Economics, 3, 183-199. https://doi.org/10.1016/0165-4101(81)90002-1

Dellaportas, S. (2006). Making a Difference with a Discrete Course on Accounting Ethics. Journal of Business Ethics, 65, 391-404. https://doi.org/10.1007/s10551-006-0020-7

Enofe, A. O., Nakpodia, J. O., \& Moruku, J. A. (2014). Ethics and Role of Accountants. European Journal of Business and Management, 6, 144-148.

Esmond-Kiger, C. (2004). Making Ethics a Pervasive Component of Accounting Education. Management Accounting Quarterly, 5, 42-52.

Fagbola, O. O., \& Popoola, S. O. (2015). Influence of Locus of Control, Work Motivation and Information Use on Decision-Making of Managers in the Aviation Industry in Nigeria. Library Philosophy and Practice (E-Journal), 12, 1-27.

Forte, A. (2005). Locus of Control and the Moral Reasoning of Managers. Journal of Business Ethics, 58, 65-77. https://doi.org/10.1007/s10551-005-1387-6

Hanjani, A., Purwanto, A., \& Kusumadewi, R. K. A. (2019). The Impact of Ethical Judgment, Locus of Control, and Organizational Commitments to Whistleblowing. Journal of auditing, Finance and Forensic Accounting, 6, 97-104. https://doi.org/10.21107/jaffa.v6i2.4937

Hastuti, S., Setianingrum, R. M., \& Sundari, S. (2015). The Influence of the Complexity of the Task, Locus of Control and Gender on the Performance of Auditors in Surubaya Indonesia. Research Journal of Finance and Accounting, 6, 140-150.

Hurrell Jr., J. J., Levi, L., \& Murphy, L. R. (2011). Locus of Control. Encyclopedia of Occupational Health and Safety.

Hung, C., \& Hsu, K. T. (2011). Impact of Locus of Control, Changes in Work Load and Career Prospects on Organisational Commitment of Employees of Life Insurance Companies during Merger and Acquisition. African Journal of Business Management, 5, 7542-7556. https://doi.org/10.5897/AJBM11.610

Ibidunni, O. M., Okere, W., Ibidunni, A. Joshua, A., \& Okah, E. (2018). Accounting Ethics and the Performance of Accounting Firms in Lagos, Nigeria. Journal of Financial Markets, 2, 10-16. https://doi.org/10.35841/finance-marketing.2.2.10-16

Igbeneghua, B. I., \& Popoola, S. O. (2011). Influence of Locus of Control and Job Satisfaction on Organizational Commitment: A Study of Medical Records Personnel in University Teaching Hospitals in Nigeria. Library Philosophy and Practice.

Jones, G., \& Abraham, A. (2007). Education Implication of the Changing Role of Accountants: Perceptions of Practitioners, Academics, and Students.

Kartasari, S. F., Tjaraka, H., \& Sudaryati, E. (2018). The Effect of Professionalism, ESQ and Locus of Control on Acceptance Dysfunctional Behaviour with Performance of Internal Auditor as an Intervening Variable.

https://knepublishing.com/index.php/kne-Social/article/view/3367/7093

Koumbiadis, N., \& Okpara, J. O. (2008). Ethics and Accounting Profession: An Exploratory Study of Accounting Students in Post-Secondary Institutions. International Review of Business Research Papers, 4, 147-156.

Nathan, D. (2015). How South African Societal and Circumstantial Influences Affect the 
Ethical Standards of Prospective South African Chartered Accountants. African Journal of Business Ethics, 9, 42-62. https://doi.org/10.15249/9-1-79

Nwakpa, P. (2010). Causes and Control of Unethical Behaviour in Tertiary Institutions in Nigeria. Academic Scholarship Journal, 2, 8-16.

O’Bryan, D., \& Donnelly, D. (2011). Locus of Control and Dysfunctional Audit Behaviour. Journal of Business \& Economics Research, 3, 9-14.

https://www.researchgate.net/publication/228754100_Locus_Of_Control_And_Dysfun ctional_Audit_Behavior https://doi.org/10.19030/jber.v3i10.2813

Ojedokun, O. A. (2008). Attitude towards Unethical Work Behaviour among Police Personnel: The Role of Emotions. Ibadan Journal of the Social Sciences, 6, 13-20.

Ornoy, H. (2010). Correlates of Employees' Attitudes towards Participation in Decision Making. IUP Journal of Organizational Behaviour, 9, 7-15.

Ozbek, V., Alniacik, U., Akkilic, M. E., \& Koc, F. (2013). The Moderating Role of Locus of Control on the Links between Perceived Ethical Problem and Ethical Intentions of Marketing Managers in Turkey. Procedia-Social and Business Sciences, 99, 265-273. https://doi.org/10.1016/j.sbspro.2013.10.494

Ozen-Kutanis, R., Mesci, M., \& Övdür, Z. (2011). The Effects of Locus of Control on Learning Performance: A Case of an Academic Organization. Journal of Economic and Social Studies, 1, 113-136. https://doi.org/10.14706/JECOSS11125

Rotter, J. B. (1954). Social Learning and Clinical Psychology. Englewood Cliffs, NJ: Prentice-Hall. https://doi.org/10.1037/10788-000

Rutledge, R. W., \& Karim, K. E. (1999). The Influence of Self-Interest and Ethical Considerations on Manager's Evaluation Judgements. Accounting, Organizations and Society, 24, 173-184. https://doi.org/10.1016/S0361-3682(98)00027-0

Sahla, W. A., \& Iryanie, E. (2018). Perception of Locus of Control, Level of Education, Machiavellianism and Ethical Reasoning against Auditor Behaviour in Audit Conflict Situations. Akrual: Jurnal Akuntansi, 10, 15-26.

https://doi.org/10.26740/jaj.v10n1.p15-26

Selart, M. (2005). Understanding the Role of Locus of Control in Consultative Decision Making: A Case Study. Management Decision, 43, 397-412. https://doi.org/10.1108/00251740510589779

Smith, A., Hume, E. C., \& Zimmermann, R. (2007).The Global Significance of Locus of Control in Ethical Decision Making: A Multi-Country Examination of University Students. Journal of College Teaching and Learning, 4, 7-12. https://doi.org/10.19030/tlc.v4i2.1625

Spector, P. E. (1982). Behaviour in Organisations as a Function of Employee's Locus of Control. Psychological Bulletin, 91, 482-497. https://doi.org/10.1037/0033-2909.91.3.482

Steinhoff, C. J., \& Hoffman, S. J. (2015). Doing the Right Thing Is Always the Right Thing to Do! Journal of Government Financial Management, 64, 13-17.

Sulistiyo, H. (2019). Locus of Control, Dysfunctional Audit Behaviour and the Mediating Role of Organisational Commitment. Quality-Access to Success, 20, 19-24.

Sulistiyo, H., \& Ghozali, I. (2017). The Role of Religious Control in Dysfunctional Audit Behaviour. Journal of Applied Business Research, 33, 1047-1058.

https://journals.indexcopernicus.com/publication/2049208/Heru-Sulistiyo-The-Role-O https://doi.org/10.19030/jabr.v33i5.10026

Susaniti, V. A. (2003). The Influence of Ethical Considerations and Locus of Control on 
Managers' Evaluation Judgements at the Adverse Selection Condition. Jurnal Widya Manajemen \& Akuntansi, 3, 19-50.

Thompson, T. S. (2010). The Impact of Locus of Control on Decision Making Styles of Mid-Level Managers. Doctoral Dissertation, Capella University, Minneapolis.

Tsui, J. S. L. (1996). Auditors' Ethical Reasoning: Some Audit Conflict and Cross Cultural Evidence. International Journal of Accounting, 31, 121-133. https://doi.org/10.1016/S0020-7063(96)90016-3

Uyar, A., \& Güngörmüş, A. H. (2013). Accounting Professionals’ Perceptions of Ethical Education: Evidence from Turkey. Accounting and Management Information Systems, 12, 61-75.

Zarefar, A., \& Zarefar, A. (2017). The Influence of Ethics and Locus of Control to Do Whistle Blowing Intention with Profession of Auditor and Non-Auditor as a Moderating Variable. Accounting and Finance Review, 2, 35-41. 